\title{
WOODWORKING TRADE AT THE TURN OF THE 19TH AND 20TH CENTURIES AND ITS PROTECTION
}

\author{
KLARA KROFTOVA ${ }^{1} \&$ LUKAS HEJNY ${ }^{2}$ \\ ${ }^{1}$ Faculty of Civil Engineering, Czech Technical University in Prague, Czech Republic \\ ${ }^{2}$ National Technical Museum, Czech Republic
}

\begin{abstract}
Part of modern monument care is not only the protection of the buildings themselves, but also their components and details created by specific craftsmanship. We can see the importance and influence of traditional crafts both on historical monuments themselves and in the collections of museum institutions. Knowledge and application of these traditional ways of processing building details will make it possible to achieve quality restoration results and also to preserve traditional crafts and sets of their individual skills and habits, usually passed down from generation to generation. The craft tradition is not only hidden in the manual way of processing, but also in the overall approach to the craft and its products. Among traditional historical crafts, woodworking trade occupies an important position, whose products - fillings of openings, shutters, wall and wainscoting, floors and others - are closely connected with the construction of the house and significantly affect both its overall architectural expression and its useful properties, e.g. the well-being of the indoor environment. The works of woodworking trade belong to the building components that wore out quickly and were subject to functional and stylistic change. These factors are the main reason why the number of authentic preserved elements is rapidly declining. In many cases, it is precisely these components of buildings that are being replaced by available industrially produced modern elements, which, however, damage the expression and monumental value of historic buildings. When restoring historic buildings, emphasis should be placed on preserving the historic original and restoring it by traditional historical methods so as to preserve the genius loci of the historic building (and the whole environment) and the craft tradition. Keywords: woodworking trade, 19th century, cultural heritage, protection.
\end{abstract}

\section{INTRODUCTION}

Woodworking trade is one of the basic crafts that has always been and is an integral part of construction production. Fine woodworking joinery products form part of the construction and include not only doors and door frames, windows and shutters, shop fronts, wainscoting, but also stairs, balustrades, elevator or telephone cabins and more. Joiners (Latin cistator, resp. formerly mensifices, mensatores) have been associated since the Middle Ages in professional guilds ("brotherhoods of craftsmen"), which, among other things, recorded the numbers of joiners and carpenters, supervised and controlled the work performed and recorded the list of products. For example in 1419 there is only one carpenter registered in the city of Prague (Bohemia), 100 years later, in 1526, 11 carpenters and joiners are mentioned [1]. Within this profession it is then possible to record a number of narrow craftsmen specializations, such as table makers, bench makers, board makers and others (Fig. 1).

The craft of a fine woodworking joiner was very often supplemented with the craft of a carpenter who prepared a rough basic construction (e.g. carpenter's door frame, carpenter's floor) and the construction carpenter supplemented them with a final layer (i.e. carpentry lining, floor friezes). In some cases, these two close trades complemented each other, in others it depended on the purpose and requirements (operational, aesthetic, etc.) for the design of the element or structure - for example, stairs that do not require fine joiner's work were performed by a carpenter and vice versa. 


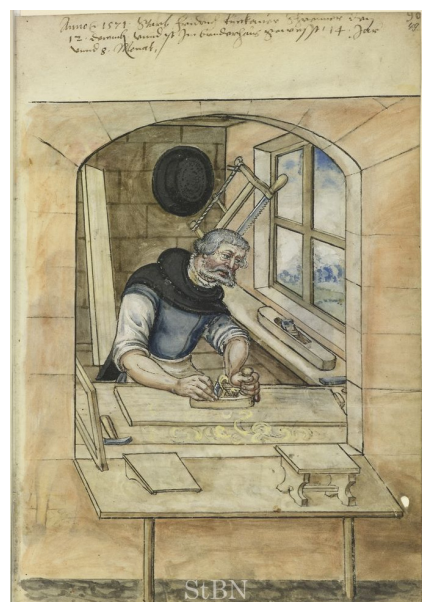

(a)

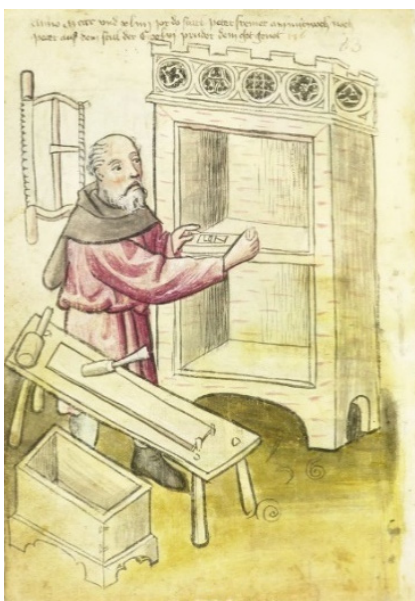

(b)

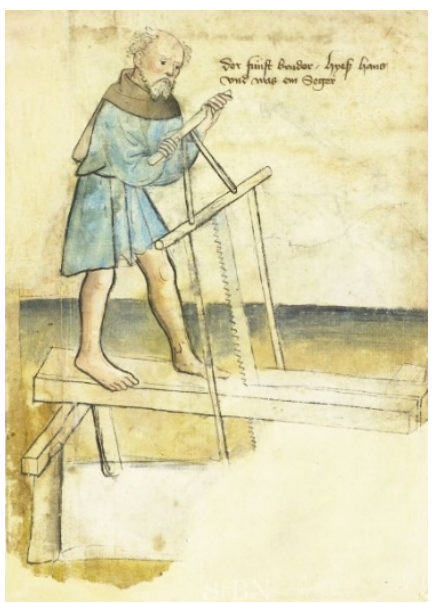

(c)

Figure 1: Carpenters brothers, resp. joiners and carpenters in historical illustrations in the Nuremberg Book of Crafts by Mendelschen and Landauer's Twelve Brothers. The illustrations show the practice of the craft, with characteristic production processes, typical tools, workshop technique, materials and products. (a) Brother Fridrich Punkauer, 1571 [2]; (b) Brother Petr, 1444 [3]; and (c) Brother Hanspilar, 1425 [4].

The basic source of information about the craft of works of woodworking trade are the works themselves. Historical iconography and period literature also play an important role, which is mainly represented by construction manuals and textbooks for university students.

\section{WOODWORKING TRADE}

The main raw material for the production of the range of construction joinery was wood, but since the second half of the 19th century in construction we have encountered a large number of new materials and structures, the introduction of which was given primarily by economic advantage. For example in the field of construction of urban tenement houses, the new innovations only manifested themselves when they became more financially advantageous than the existing solution, or when it was not possible to achieve the desired goal in any other way. The ever-tightening fire and building regulations were also a significant impulse (comprehensive fire protection regulations date back to the 17th century, the first major positive legal acts are the laws of 1873 and 1876, which issue the Fire Police Order and the Fire Order for the Kingdom of Bohemia, Moravia and Silesia). The industrialization of production and mentioned innovations have led to a reduction in the share of joinery products in construction and, as a result, to simplifications and a certain decline in the joinery trade in the 20th century (Fig. 2). These changes were also closely related to the development of architecture and means of expression.

The choice of a tree species was primarily influenced by the requirements for the properties of wooden structures and individual elements. A secondary role was played by the composition of forest stands at a specific moment, and thus also by the availability of the necessary dimensions and the amount of selected material. "For joiners and carpenters, wood is always sought after, mature, dense, straight, healthy and, as far as possible, without 


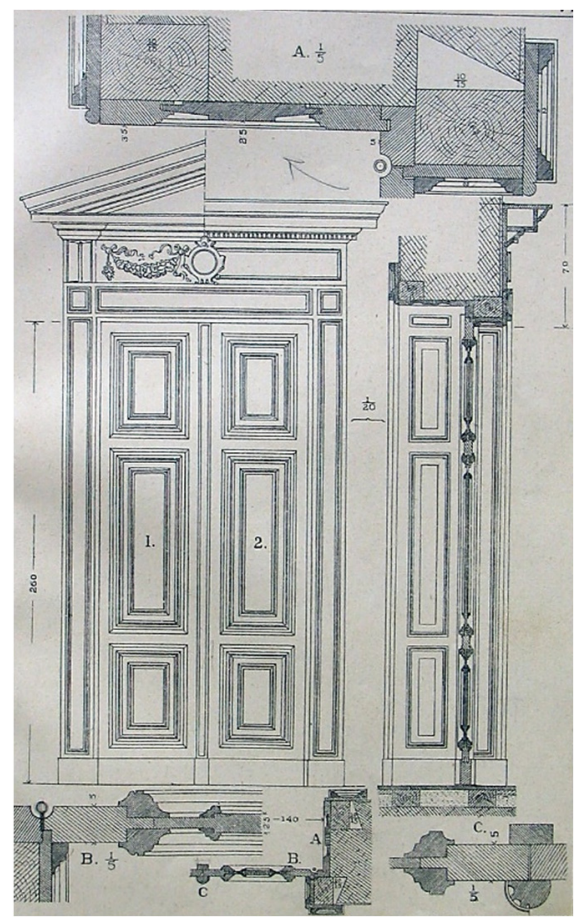

(a)

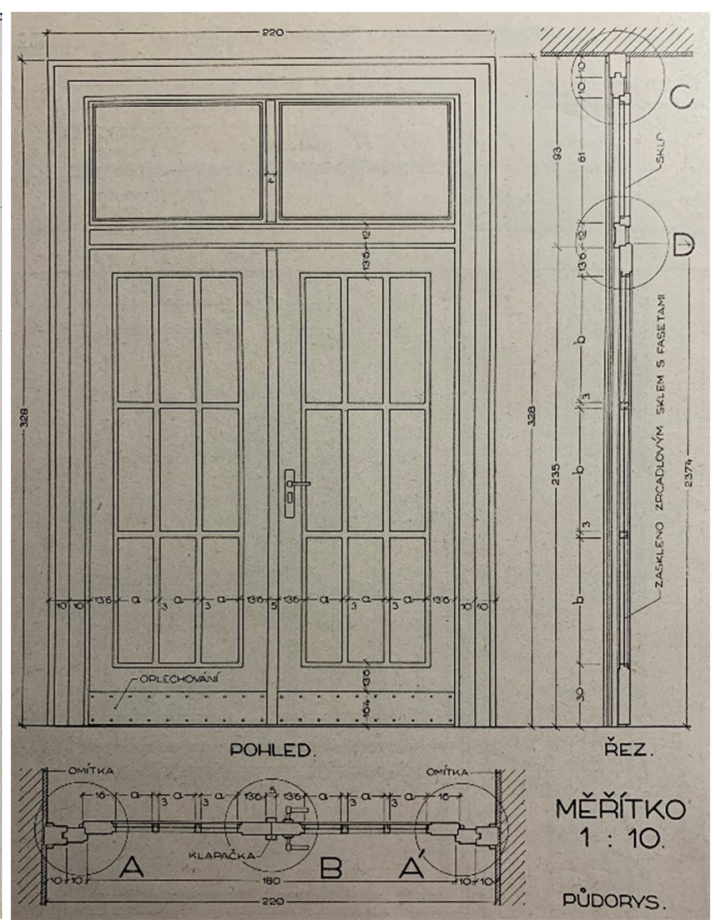

(b)

Figure 2: The shift from ornate design to simplicity on the design of a double leaf entrance door. (a) Design of a door with a rich profile for a city apartment building in the construction manual from the end of the 19th century [5]; and (b) Simplified design of a door to an apartment building from a textbook for industrial schools from the 1940s [6].

knots..." [7]. Among the types of wood used in construction joinery was mainly mature core wood of pine, spruce, larch and oak, which shows very good mechanical properties and higher durability of structures made of it (Fig. 3). Pine, larch and oak have a more durable and colorful core wood compared to spruce wood, whose wood is light, soft and easy to work with. Pine wood is heavier than spruce wood, shows smaller dimensional changes and, thanks to its higher resin content, is characterized by a longer durability. Larch wood, like pine, contains more resin, is well machined, but tends to twist when not sufficiently dried. Due to its properties, heavy, strong, flexible and biotic wood-destroying agents, oak wood is suitable for use in constructions with an increased demand for their mechanical properties and especially durability in an environment with increased humidity [8].

Vitruvius already states in his Ten Books on Architecture [9] that wood should be felled in the winter, when it has the least sap. The rules for the drying process then applied to the individual woody plants: e.g. "The deciduous trees are either whole or helically cut from the bark to make the wood dry faster and the membrane to harden. the moisture did not evaporate quickly, otherwise the trunk would rupture." [7].

In order to avoid dimensional changes in already finished products, it was necessary for the wood for joinery structures to be dried to $8-12 \%$ moisture content before its further 


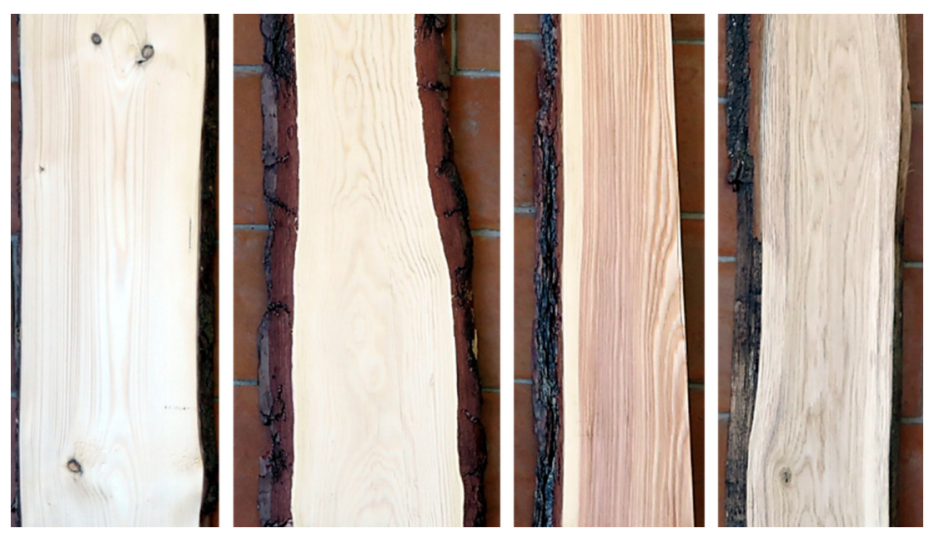

Figure 3: Types of wood used in parts of traditional building joinery. From left spruce, pine, larch, oak [8].

processing. "The wood to be used for joinery work must be dried properly beforehand; air dried wood - i.e. slowly - always has better properties than wood dried and roasted in chambers. However, it needs to air dry: 3-4 years of soft wood, up to 5 years of hard wood, 8-10 years of thicker boards from the time of felling; in addition, it is advisable and highly recommended to dry the wood before processing on a bunk bed or worse, or even in a chamber, kiln." [7] The joinery products were therefore prepared in a workshop from dried planed lumber and were subsequently installed in their place on the construction site.

The prepared parts made of dried and processed wood were joined by structural joints so as to form a solid unit. Joints, which varied according to the type of joint, the type of construction and others, were made as dry or secured with bone glue. If necessary, the connection was reinforced with pins, wedges, tapes, screws or nails. One of the basic joints used was a ledge joint, which, for example, connected the boards of the door leaf. Among others, it is possible to mention mainly the mortise and tenon joint, open-slot mortise joint, bridle joint and dovetail (Fig. 4). Compared to the carpenter, the joiner used a relatively limited number of joints, which he adjusted according to the specific purpose of use.

The demands on the necessary space of the manual joiner's workshop were small, its center was the so-called workbench, on which the entire production process took place. The basic equipment also included the so-called shaving horse work bench - a bench for securing the product when working with a timber shave and an adjustable woodworking bar clamp for supporting the processed element. Each joiner's workshop then contained various types of tools - saws, planes, chisels, gimlets, drill bits, joiner's clamps and more (Fig. 5). With the overall industrialization of the company during the 19th century and with the advent of machining, a number of changes entered the joiner's workshop. In manual joinery production, the need for space necessary for the placement of machines and handling space around them was eliminated. The integration of the machines into production was reflected in the change of the spatial scheme of the workshop and the requirements for the floor area increased to ensure its efficient operation. During the 19th century, woodworking machines for cutting material gradually appeared in carpentry shops, mainly band saws (banding machines), spindle moulder (leveling) and thicknesser machines (planers and broaching machines) and others (Fig. 6). 

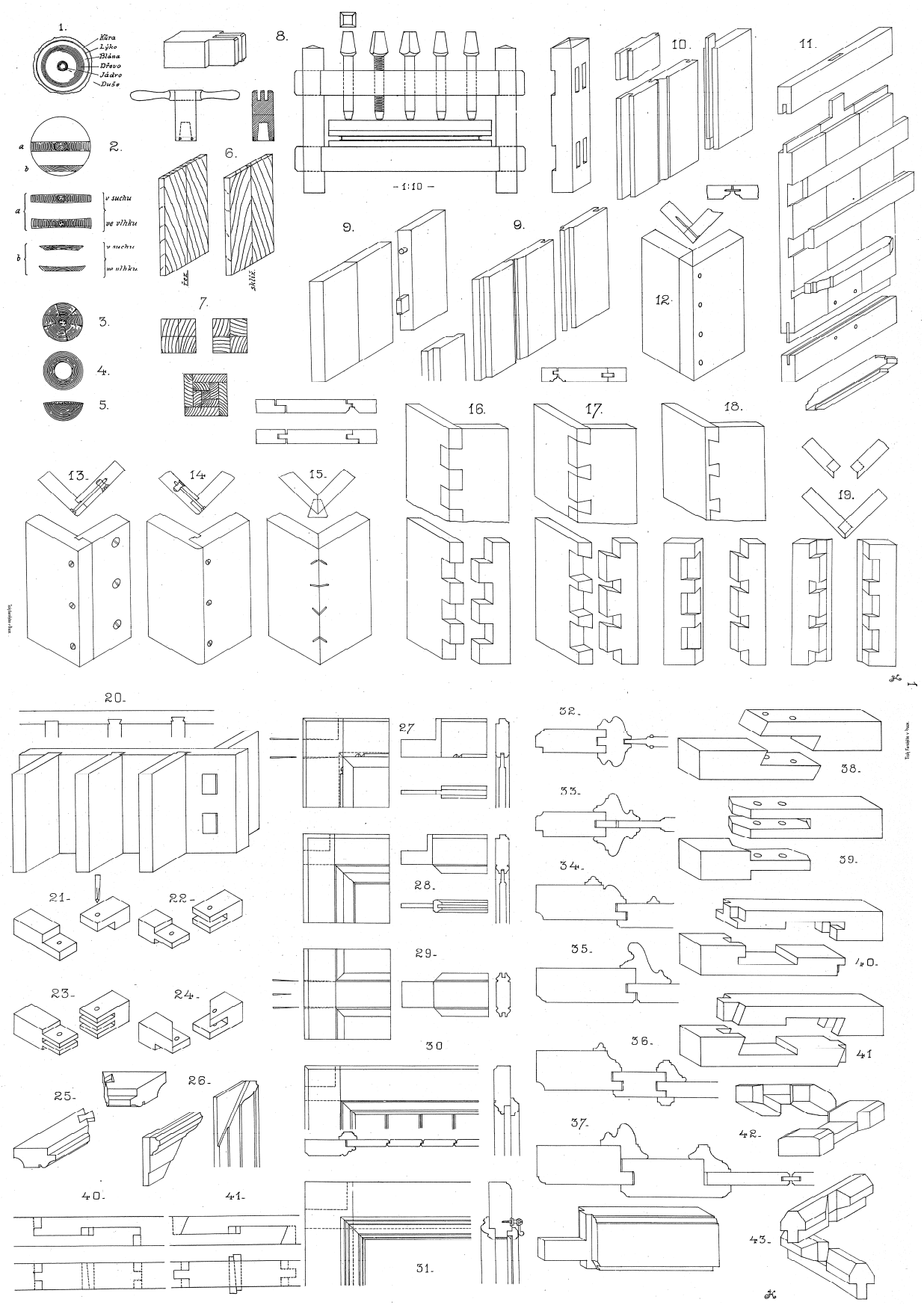

Figure 4: Details of the design of the most frequently used joinery joints, such as ledge joint, mortise joint, tenon joint, bridle joint and dovetail, given in the worksheets of the professor and government commissioner of industrial schools, Ing. Jan Kubeš [7]. 


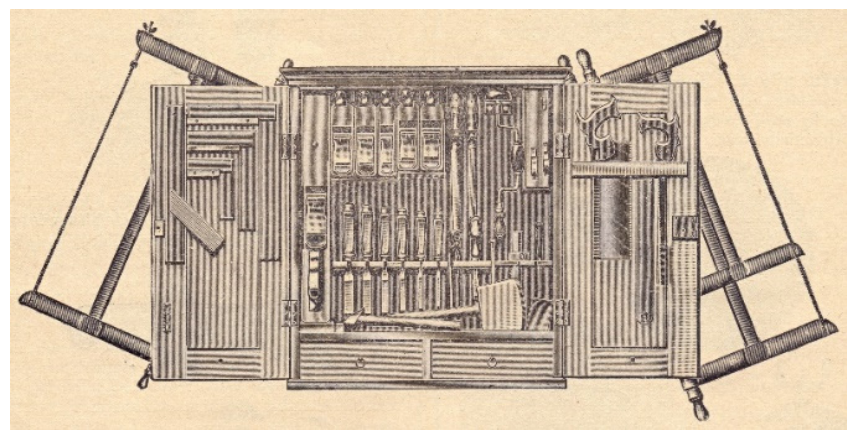

(a)

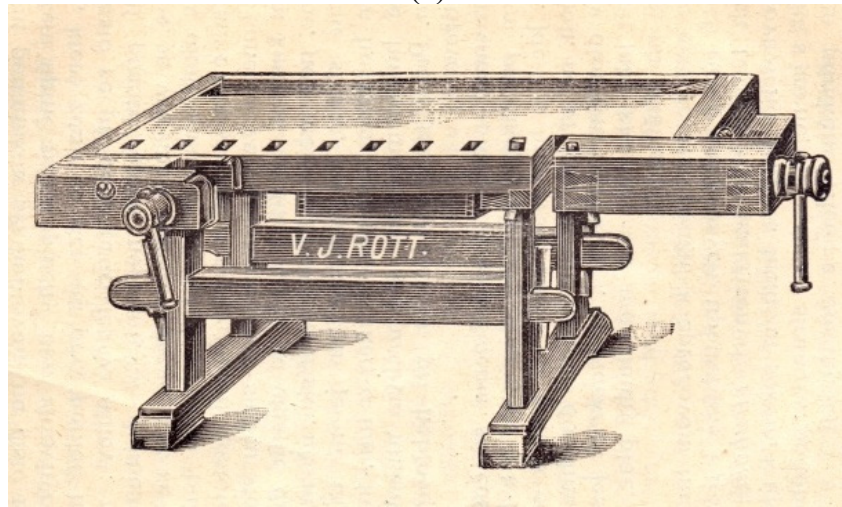

(b)

Figure 5: Characteristic equipment of a carpentry workshop with manual machining of material. (a) Basic tools for manual woodworking and their practical storage [10] and (b) Workbench - the necessary equipment of every manual carpentry workshop [11].

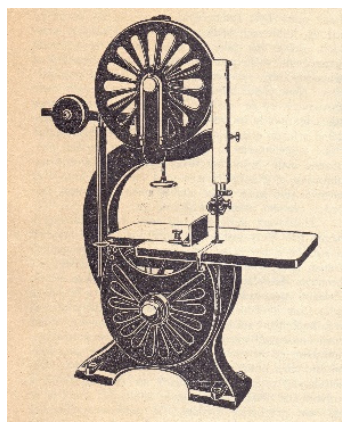

(a)

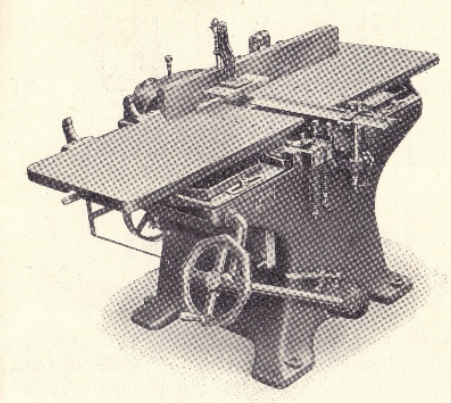

(b)

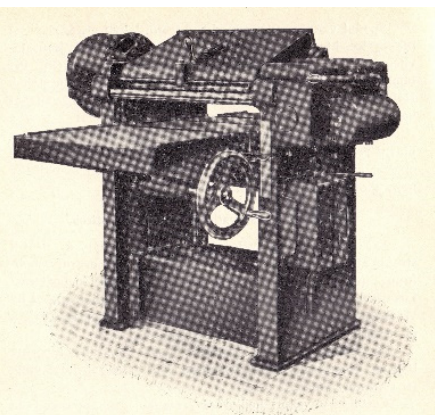

(c)

Figure 6: Examples of carpentry workshop first machinery for cutting and planing material from the beginning of the 20th century. (a) Band saw [12]; (b) Spindle moulder; and (c) Thicknesser [13]. 


\section{PRODUCTS OF CONSTRUCTION JOINERY}

As mentioned above, joinery products form an integral part of buildings and play a significant role in their architectural and artistic expression. Simultaneously with the elements of construction joinery, we are regularly in direct contact - we take the door handle on a daily basis, open windows daily, pass shop fronts daily, etc. In addition to the aesthetic function, the utility and economic functions also play an important role here. Not only for these reasons, emphasis has been placed in history on both the durability and quality of construction joinery products as well.

On individual products - doors, windows, shop fronts, wainscoting, etc., we can observe their design, surface treatment and the development of architecture and artistic perception, given that all elements of construction joinery reflected the contemporary aesthetic opinion (Fig. 7). In general, in everyday production it is possible to notice a change from decorative to elegant and simple design, not only in artistic expression, but also in the detail of profiling, surface treatments and accessories.

Especially, the production of the 19th and early 20th century occupies an important position due to the fact that a large number of buildings of urban and village architecture come from this period. Unlike most older monuments, however, these buildings have largely preserved fillings of openings and other joinery components.

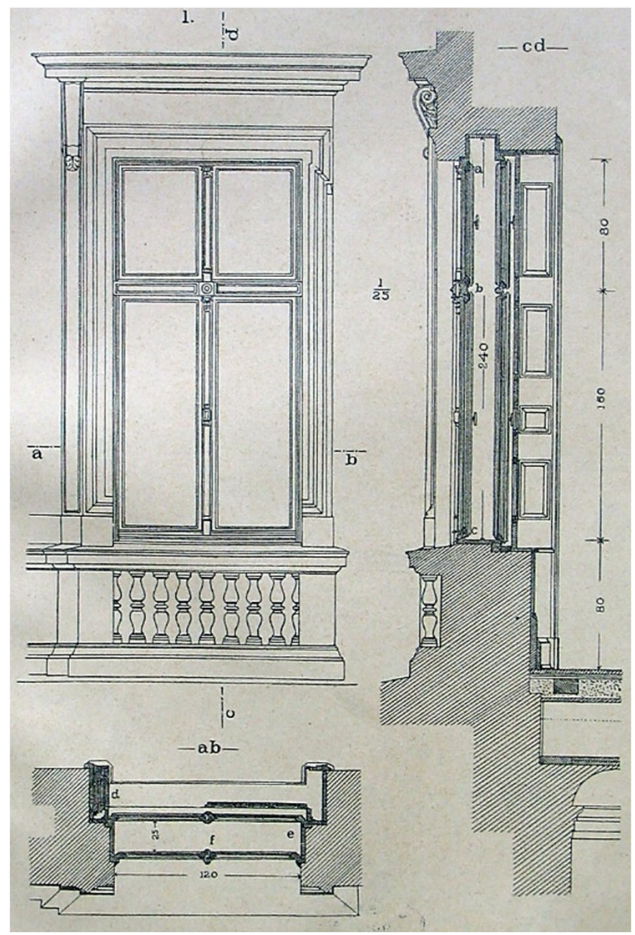

(a)

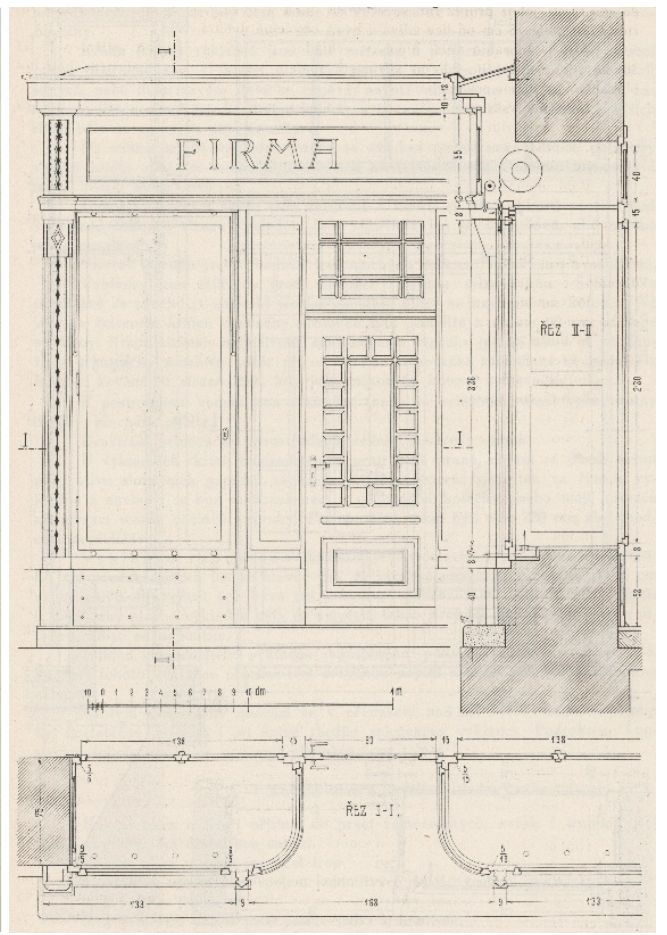

(b)

Figure 7: Design of joiner's products. (a) Design of a double window in a town apartment building from the end of the 19th century [5]; and (b) Design of a shop window for a town apartment building given in the construction manual from the beginning of the 20th century [14]. 


\section{PROTECTION AND RESTORATION OF CONSTRUCTION JOINERY WORKS}

An important cultural and historical value is the artistic contemporary expression, while each period had its artistic ideals, which it tried to achieve. The created artistic quality retains the ability to address contemporary society, even if the current expression is different. Historic architecture offers details (e.g. brass window handles), elements (e.g. door panels or window frames), facades and, last but not least, the overall environment, the preservation of which makes sense for our society. Likewise, care for the preservation of traditional crafts, knowledge of the production and processing of traditional materials should be part of the cultural heritage.

The rescue of valuable works of construction joinery is one of the most difficult tasks with which we can meet in the field of monument care. At present, unfortunately, quality joinery products are still being removed, the qualities of which - artistic, architectural, craft and especially monumental - can hardly be achieved by replacing them with new products. In the context of monument care, it is necessary to emphasize the value of the historical original, which tells about the time of its origin and is the bearer of the mentioned cultural and historical values. Only from the original it is possible to draw information about the aesthetic feeling, creative abilities and historical technical skills. Closely related to this requirement is traditional crafts and materials, the use of which makes it possible to restore a historic building without changing its architectural expression. The use of a different material and a different treatment would be reflected not only in the appearance but also in the way of aging which is important characteristic of each material. Contemporary material alternatives can be functionally comparable, but from the point of view of monument care, the use of traditional material has value in itself and is in principle irreplaceable.

Therefore, an analysis of the values of the preserved joinery components should be done at the beginning of each renovation, and only if it is clear that the preserved elements do not have a monumental value or the requirement to preserve them would not be proportionate to this value. The decision on whether it is necessary to replace the work of construction joinery with, for example, a replica, must be approached sensitively, especially for listed buildings, where the effort to preserve the original components is one of the priorities. In these cases, it is appropriate to make a thorough documentation of the finding situation and replace the element with a copy, or replica. However, even in the case of unprotected buildings, the refurbishment of joinery elements should be preferred to replacement, with which there is always simplification and loss of historical information. At the same time, an improper decision, for example replacement of joinery products, can significantly damage the appearance of the building and degrade the monument, respectively the historical value of the object.

The principle of renewal of joinery elements consists in the replacement of long-lived parts on a small scale, when there are no changes in structure or material, in profiling, or in the method of mounting or opening. During this process, the technical parameters of the joinery components of the building can be improved, for example, by additional insertion of elements, which does not change the structure or profile (e.g. interruption of the thermal bridge, or reduction of air permeability of windows).

\section{CONCLUSIONS}

The works of construction joinery represent parts of buildings with an unforgettable cultural value, which is very important for the quality of our environment. The priority interest of society and monument care should be the protection of preserved historical elements and the extension of their lifespan. 
When restoring the works of construction joinery, it is important to respect the requirements for preserving the principle of authenticity and monumental values (value of age, artistic value, historical value). The preferred approaches include the refurbishment of joinery elements, in which a substantial part of the original material is preserved, and thus also the authenticity and monumental values.

\section{ACKNOWLEDGEMENT}

This article was written as part of the NAKI DG18P02OVV038 research project "Traditional City Building Engineering and Crafts at the Turn of 19th and 20th Centuries" (2018-2022, MK0/DG).

\section{REFERENCES}

[1] Winter, Z., Dějiny řemesel a obchodu v Čechách v XIV. a v XV. století, Praha, p. 449, 1906.

[2] Amb. 279.2 Folio 49 recto (Landauer I) [online], Die Hausbücher der Nürnberger Zwölfbrüderstiftungen (nuernberger-hausbuecher.de). Accessed on: 13 May 2021.

[3] Amb. 317.2 Folio 66 verso (Mendel I) [online], Die Hausbücher der Nürnberger Zwölfbrüderstiftungen (nuernberger-hausbuecher.de). Accessed on: 13 May 2021.

[4] Amb. 317.2 Folio 1 recto (Mendel I) [online], Die Hausbücher der Nürnberger Zwölfbrüderstiftungen (nuernberger-hausbuecher.de). Accessed on: 13 May 2021.

[5] Pacold, J., Konstrukce pozemního stavitelství. Práce tesařské, pokrývačské a truhlářské, podlahy, stropy a schody dřevěné, part I, Praha, p. 71, 1900.

[6] Ondřej, S., Stavba domu v praksi, Praha, pp. 321, 1932.

[7] Kubeš, J., Truhlářství stavební i nábytkové, Plzeň, pp. 2-21, 1895.

[8] Hejny, L., et al., Stavebni truhlářstvi a parketářství, Praha, pp. 59-63, 2020.

[9] Vitruvius, M.P., Ten Books on Architecture, Translation D. Rowland, Cambridge, 1999.

[10] Technický obzor pro moderní zpracování dřeva, 1. ročník, Klášterec nad Ohří, 1929.

[11] Axamit, J., Domácí dílna, její zařizeni a práce v ní. II. díl, Zpracováni dřeva, Praha, 1928.

[12] Technický obzor pro moderní zpracování dřeva, 1. ročník, Klášterec nad Ohří, 1929.

[13] Kouřil, J. et al., Odborná nauka truhlářská pro odborné pokračovaci školy, part 1, Praha 1934.

[14] Kohout, J. \& Tobek, A., Konstruktivni stavitelství, Tesařství a stavebni truhlářství, Jaroměř, p. 245, 1915. 